\title{
Using Real-Time PCR to Investigate Some of Antibiotic Resistance Genes from Streptococcus agalactiae Isolates from ewe Mastitis cases in Nineveh province
}

\author{
Dr. Ayman Albanna ${ }^{1^{*}} \quad$ Dr. Aseel A. H. Al-Layla ${ }^{2}$
}

${ }^{1}$ College of Environmental Science \& Technology, Mosul University, Mosul, 41002, Iraq, aymanaallbanna@gmail.com, 009647719623166, ORCID ID: https://orcid.org/0000-0002-8514-2774

${ }^{2}$ College of Sciences, Department of biophysics, University of Mosul, Mosul, 41002, Iraq, aseelaallayla@ gmail.com, 009647719623199, ORCID ID:https://orcid.org/0000-0002-7084-0115

*Corresponding author: aymanaallbanna@gmail.com

Received 7/3/2019, Accepted 26/1/2020, Published 8/9/2020

This work is licensed under a Creative Commons Attribution 4.0 International License.

\begin{abstract}
In this study, from a total of 856 mastitis cases in lactating ewes, only 34 Streptococcus agalactiae isolates showed various types of resistance to three types of antibiotics (Penicillin, Erythromycin and Tetracycline). St. agalactiae isolates were identified according to the standard methods, including a new suggested technique called specific Chromogenic agar. It was found that antibiotic bacterial resistance was clearly identified by using MIC-microplate assay (dilution method). Also, by real-time PCR technique, it was determined that there were three antibiotics genes resistance ( $\mathrm{pbp} 2 \mathrm{~b}$, tetO and mefA ). The high percentage of isolate carried of a single gene which was the Tetracycline $(20.59 \%)$ followed by percentage Penicillin was $(17.65 \%)$ and the lowest was in Erythromycin $(11.77 \%)$. However, there were many isolates that carried two genes of antibiotics resistance represented by Penicillin and Erythromycin with collective present of $38.22 \%$, and for the Penicillin and Tetracycline, the percentage was found to be $11.77 \%$. In contrast, no common gene with two antibiotics (Erythromycin and Tetracycline) was detected. On the other hand, it was found that no bacterial sharing with three kinds of antibiotic resistance genes ( pbp2b, tetO and mefA ). This study has revealed that the St. agalactiae isolates did induce recurrent mastitis in lactating Iraqi's ewes.
\end{abstract}

Key words : Antibiotics resistance, Animal public health, Mastitis, Real time PCR, Streptococcus spp.

\section{Introduction}

Mastitis is one of the most crucial diseases in lactating farm animals causing a subsational lose to sheep owners around the world (1). Streptococcus agalactiae is one of the significant bacteria that cause inflammation of the mammary glands in ewes resulting in decreasing milk yeild. It is a Gram positive bacteria that belong to the beta group and called a Group B Streptococcus or GBS (2, 3). Furthermore, Streptococci are the general group of bacteria causing mastitis in sheep after Staphylococci species $(4,5)$. S. agalactiae, have many virulence factors responsible for pathogenicity, including aggregation factor, glutamine synthetase and others, such as those resistant to antibiotic as (Penicillin, Erythromycin and Tetracycline). Antibiotic resistance is considered a critical issue in treating many cases of mastitis, and they possess genes resistance whcih are randomly accquaired. Usually, bacteria become resistant for certain antibiotics by horizontal procuration of resistance genes through or transposons plasmids. It can take place by integrating DNAresistance gene into the chromosome, and also reassortment DNA-nucleotides in several chromosomal site, thus resulting in mutations (6). This is due to a misuse of antibiotics in 
treating mastitits as well as the grwoth factor in sheep nutrition. The mechansim of antibiotic resistance is directly in charge of many cases of diseases treated with penicillin, tetracycline, erythromycin and others $(5,7)$. Usually, in Nineveh region the commmon traditional treatment of sheep and goat mastitis is performed using antbiotics without sensevity test. Evenually, the bacterial become more adapted and the relive, accordingly, is less secure and more virulance.

The purpose of this study is to detect the presence or abcence of three differnet antibiotic resistance genes ( $p b p 2 b$, tet $O$ and mefA ), already decided for this inevstigation. $S$. agalactiae isolates were isolated from lactating ewes, suffering from recurrent mastitis. Moreover, the realization of a minimum inhibitory concentration (MIC) of antibiotic resistance is to be an existed gene that carrying whole information about the influence of antibiotics on mastitis.

\section{Materials and methods \\ Collections Samples}

About 856 samples of milk were obtained from ewes mastitis cases from vet medical clinics at Nineveh province. The milk samples were placed into sterile test tubes and conveyed directly to the lab under low temperture via the ice bucket. Then, each sample was inoculated on a standard microbiological media.

\section{Isolation and Identification}

Firstly, one drop of milk sample was streaked out on blood agar and incubated at $37{ }^{\circ} \mathrm{C}$ for 24 hours. Then, the culture was examined with regard to positive Gram's stain and morphology (hemolytic beta group). Moreover, all positive suspected colony for streptococcus species were recultured on Luria Bertani agar (LB) at $30^{\circ} \mathrm{C}$ for 24-48 hours with $5 \% \mathrm{CO} 2$. Then, a single colony was streaked out on spesfic anaerobic chromogenic agar at $37^{\circ} \mathrm{C}$ for 24 hours inorder to idetitifed $S$. agalactiae in accordance with chromogenic agar test kit (CHROMagarTM StrepB) (8). Furthermore, all isolates were asserted by Christie-Atkins-Munch-Petersen test (CAMP) (9). Finally, all isolates were added $20 \%$ DMSO and kept at $-80^{\circ} \mathrm{C}$ ultra-freezer. The steps of the current experiment procedures are illustrated as in Fig. 1.

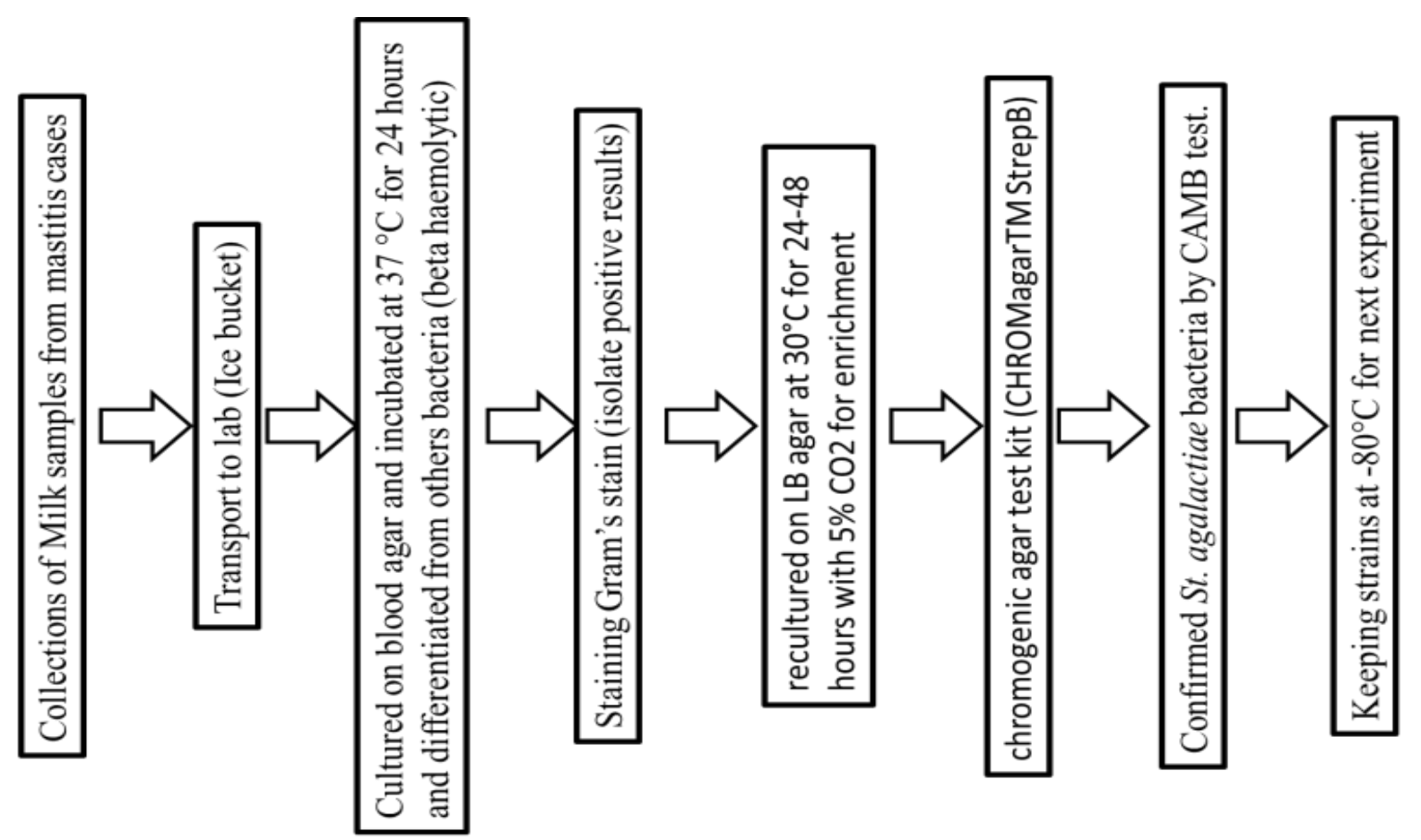

Figure 1: Step by step of the collection sample, bacteriological standards identified and preservation of the isolation of $S$. agalactiae. 


\section{Bacterial Activation}

The entire 34 strains samples were directly taken from frozen $-80^{\circ} \mathrm{C}$, isolated from sheep suffered from mastitis cases across Nineveh province. All strains were reactiviated in $5 \mathrm{~mL}$ LB broth and incubated at $30^{\circ} \mathrm{C}$ for $24-48$ hours with 5\% $\mathrm{CO} 2$ environment and shaked at 150 rpm.

\section{Microplate MIC Assay \\ Microplate minimum inhibitory} concentration assay for detecting isolates poossed antibiotic resisitance ablility by using the microdilution method according to Clinical \& Laboratory Standards Institute protocol (CLSI) $(10,11)$. Cultures were prepeared to start growth at an OD600 $=0.01$ in $3 \mathrm{ml}$ of LB broth $(5 \% \mathrm{CO} 2)$ and allowed to grow until reaching OD600 $=0.15$. Each microplate well was prepared with $10 \mu \mathrm{l}$ of each of penicillin, tetracycline and erythromycin, starting dilution from $(0.125,0.25,0.5,1,2,4,8,16,32,64,128$ and $256 \mu \mathrm{g} / \mathrm{mL}$ ), then, they were compared to the control (without adding antibiotic). Each well was added to $190 \mu \mathrm{l}$ culture and the final volume was $200 \mu \mathrm{l}$ per well. The whole microplate was sealed with a gas-permeable membrane and incubated $30^{\circ} \mathrm{C}$ for 24 hours. The plate reader (Bio-Rad) was adjusted to measure the optical density. all results were analyzed with Graphpad Prism 6 program.

\section{Real-time PCR technique}

\section{Genome extraction and purification}

All strains were cultured on LB plate at $30^{\circ} \mathrm{C}$ ( $5 \% \mathrm{CO} 2$ ) for 24 hours and then inoculate single colony into the $3 \mathrm{~mL} \mathrm{LB}$ broth with specific antibiotic and grown up until reached OD600 $=0.5$ (12). Genomic DNA was extracted and purified using Promega genomic DNA and Purification kit in accordance with the manufacturer's protocol. The DNA concentration was valued by using Nanodrop NA1000.

\section{Primers Design}

Real-time PCR primers were designed By the National Center for Biotechnology Information website (NCBI). Each of the Penicillin ( $p b p 2 b)$, Erythromycin (mefA) and Tetracycline (tetO) genes was identified in the bacterial genome (Table 1). All primers were synthesized by Integrated DNA Technologies Company (IDT).

Table 1: Real time PCR primers for antibiotic resistance genes.

\begin{tabular}{lllll}
\hline Gene & $\begin{array}{l}\text { Primer Forward } \\
\text { Sequence }\end{array}$ & $\begin{array}{l}\text { Primer Reverse } \\
\text { Sequence }\end{array}$ & References & $\begin{array}{l}\text { Gene } \\
\text { length(bp) }\end{array}$ \\
\hline Erythromycin $(m e f A)$ & ATCACTAGTGC & ACTAAAAGTGG & In this study & $1,218 \mathrm{pb}$ \\
Tetracycline $(t e t O)$ & ATTCTGGCTCAC & ATATCGTCA & In this study & $1,920 \mathrm{pb}$ \\
Penicillin $(p b p 2 b)$ & ATTCTCAGGTGG & ATAGGTGTTGG & In this study & $2,058 \mathrm{pb}$ \\
\hline
\end{tabular}

\section{Diagnosis of antibiotic resistance genes (Real time PCR)}

An experiment was carried out, using a Bio-Rad real time PCR machine to determine antibiotic gene resistance. Each well volume was $20 \mu \mathrm{l}(1$ $\mu \mathrm{l}$ forward and reverse primers $20 \mathrm{pmol} / \mu \mathrm{l}, 9$ $\mu \mathrm{l}$ SYBR Green Promega Master Mix and $10 \mu 1$ DNA).

Then, a standard curve was determined by using different serial dilutions of genomic $(0.00032,0.0016,0.08,0.04,0.02,0.1)$, in order to set a template DNA concentration inside the linear zone for unknown samples. Analysis of samples was used by $\triangle \mathrm{CT}$ Real time PCR technique depending on the initiation frequency of template of DNA detection (13). All experiments were performed in biological triplicate bases. (statistical analysis)

\section{Results \\ Isolation and Identification}

Out of 856 diagnosed mastitis, it was observed that $112(13 \%)$ cases were identified as Streptococcus agalactiae, with 78(9\%) sensitive for antibiotics. While, 34(4\%) were resistant for the three different included 655(76\%) Staphylococcus genus, whereas, $89(11 \%)$ identified as another sorts of bacteria. antibiotics (Penicillin, Tetracycline and Erythromycin). However, there were $744(77 \%)$ isolates(Table 2). 
Table 2. Classification and the percentage of diagnosis

\begin{tabular}{lllll}
\hline Diagnosed & \multicolumn{2}{l}{ Streptococcus agalactiae $\mathbf{= 1 1 2}(\mathbf{1 3 \%})$} & \multicolumn{2}{c}{ Others causative agents $\mathbf{= 7 4 4 ( 8 7 \% )}$} \\
\cline { 2 - 5 } mastitis $=$ & Resistance for & Staphylococcus & Other sorts of \\
& Sensitive for Antibiotics & Antibiotics & genus & bacteria \\
& $78(9 \%)$ & $34(4 \%)$ & $655(76 \%)$ & $89(11 \%)$ \\
\hline
\end{tabular}

\section{Microplate MIC Assay}

Thirty four strains St. agalactiae were tested for their ability to resistance and sensitivity, by using three different antibiotics (Penicillin, Erythromycin, Tetracycline). Microplate assay (MIC) has shown how some of strains have susceptible and resistance trends against one or two of the experimental antibiotics, simultaneously. The results have revealed $6(17.65 \%)$ of samples were Penicillin resistance, while, 4(11.77\%) were resistance Erythromycin. Also, 7(20.59\%) of samples were

resistance Tetracycline (Fig.2).

Furthermore, there were samples characterized by having resistant for more than one antibiotic. In terms of resistance Penicillin and Erythromycin, there were $13(38.22 \%)$ samples, whereas resistance Penicillin and Tetracycline were just $4(11.77 \%)$ from samples. In contrast, no resistance was found in terms of sharing Erythromycin and Tetracycline together. Also, as for the resistance the three types of antibiotics (Penicillin, Erythromycin, Tetracycline), no such case in the field of this study has been found (Fig.3).
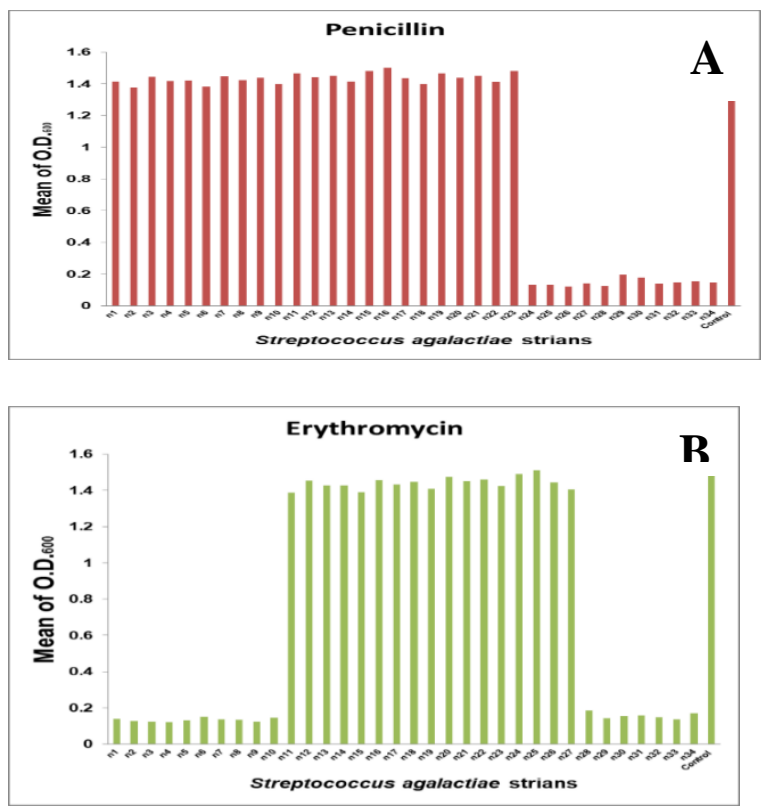

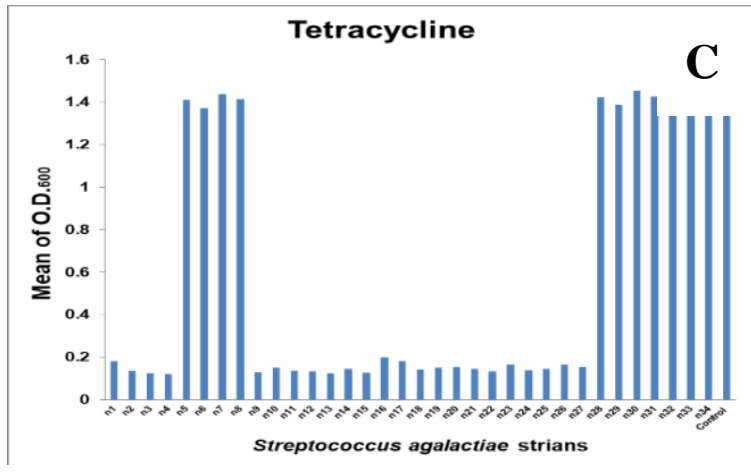

Figure :2 Micro-plate assay for testing 34 isolates of S.agalactiae about their ability to resistance or sensitivity against different concentrations of antibiotics. (A). 23 strains have resistance against Penicillin (B). 17 strains have resistance against Erythromycin (C). 11 strains have resistance against Tetracycline

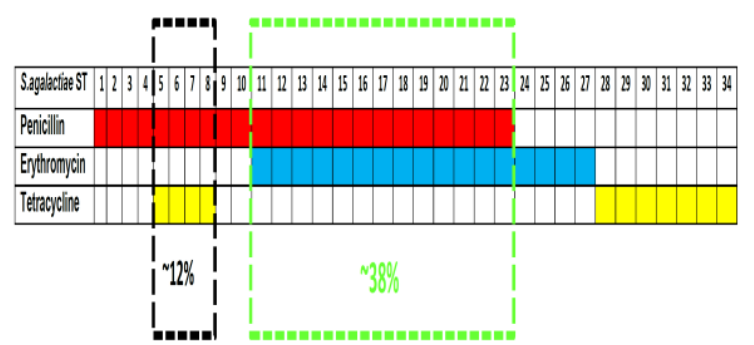

Figure : 3 The colour-codes illustrate some of S.agalactiae isolates have shared with two antibiotics resistance in particular Penicillin with Erythromycin $(\sim 38 \%)$ and penicillin with Tetracycline $(\sim 12 \%)$. However, there are no isolates have resistance Erythromycin and

Tetracycline. While, no presence was observed any of isolations having resistance for three antibiotics together.

detection, through determining the antibiotic gene resistance ( $p b p 2 b$, tet $O$ and mefA ) for 34 S.agalactiae isolates. DNA genome dilution series were examined as standard curves to identify the best of an average phase dilution (0.04), which gave the 
optimal expression for this experiment. The gene $p b p 2 b$ existed in 23 strains, while tet $O$ gene was found in 11 strains. In terms of mefA the gene was present in 17 strains (Fig.4). Astonishingly, the results of Real time PCR for three genes were $100 \%$ compatible with Microplate MIC assay results for detection Penicillin, Tetracycline and Erythromycin resistance genes versus the minimal inhibitory concentration of antibiotics, respectively.

Moreover, the expression of stability for each antibiotic gene differs from others genes when compared to each other.. In terms of Penicillin, the time gene expression comes up after 4 minutes, while, the magnitude was 120 rate fluorescent units (RFU). In comparison the Pencillin, the period of Tetracycline gene expression was at 12 minutes with magnitude 60 RFU. On the other hand, in Erythromycin, the time of gene expression at 8 minutes with amplification size was 24 RFU (Fig.4)

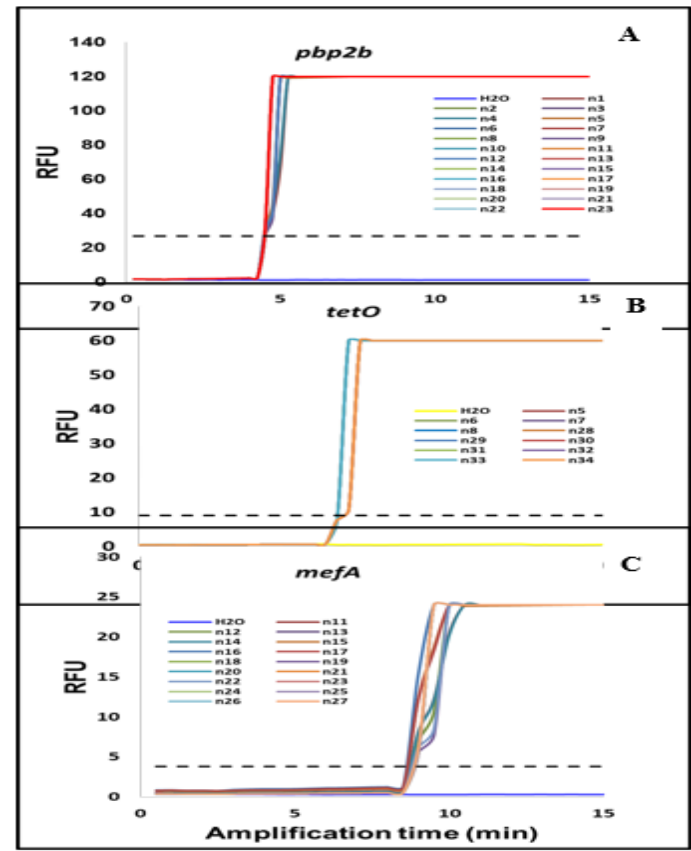

Figure :4 Real time PCR assay of three antibiotics resistance genes ( $p b p 2 b$, tet $O$ and $m e f A)$. A). 23 strains were found $p b p 2 b$ gene. B) 11 strains were detected tet $O$ gene. C) 17 isolates were detected mefA gene. Overall, there are different of log-phase for each gene that give us indication for detection specific antibiotic gene based on which concentration of genome used, and the amplification time. Discussion
All positive isolates $S$. agalactiae showed resistance to different antibiotics phenotype (Penicillin, Erythromycin and Tetracycline). Also, the tests were confirmed by the Real time PCR technique based on Yuexia's method (5). Only three different genes $(p b p 2 b$, tetO and $m e f A$ ) of antibiotics resistance were identified in 34 isolates distributed for high percentage starting Penicillin then Erythromycin and Tetracycline. Regarding Penicillin, 23 samples were first identified by using Microplate MIC assay that showed positive results. The 23 samples, after that, they were confirmed by Real time PCR technique where $p b p 2 b$ gene was recognized, which is ( $p b p 2 b$ gene) certainly responsible for Penicillin resistance phenomena. It was found that 6 samples $(17.65 \%)$ which possessed only one gene were resistant to the Penicillin antibiotic. This might be due to the fact that the sheep owners are over using Penicillin antibiotic to treat their sheep even for trivial reasons or for enhancing growth rate and milk production in such cases $(14,15)$. It appears that the genetic entity of the farm sheep under this study has gained some resistance to the Penicillin antibiotic (1618). The 13 samples $(38.22 \%)$ had positive resistance results to another antibiotic, the Penicillin shared resistance alone with Erythromycin. In turn, only 4 samples $(11.7 \%)$ showed resistance to Tetracycline in conjunction with Penicillin, too. These results confirmed the fact that Penicillin antibiotic was over used by the owners which created bacterial resistance to this antibiotic (Penicillin). In this regards and from personal communication, according to $(19,20)$ it was observed that most mastitis cured cases by penicillin were ineffective.

Regarding the Tetracycline antibiotic, results of this study indicated that $20.59 \%$ of cases were positive which contained tet $O$ gene only. It suggested that the dissimilarity in Tetracycline resistance genes might be due to possible variation in versions of Tetracycline available in the market. With respect to Erythromycin antibiotics, it is common that there are two erythromycin resistance genes erm and mefA (5). However, it was found in this study that only mefA gene was detected. The results of this study coincide with other findings (21). 


\section{Authors' declaration:}

- Conflicts of Interest: None.

- We hereby confirm that all the Figures and Tables in the manuscript are mine ours. Besides, the Figures and images, which are not mine ours, have been given the permission for republication attached with the manuscript.

- The author has signed an animal welfare statement.

Ethical Clearance: The project was approved by the local ethical committee in Mosul University.

\section{Acknowledgment}

The authors are very grateful to the University of Mosul / College of Environmental Science and Technology for their provided facilities, which helped to improve the quality of this work.

\section{References}

1. Olechnowicz J, Jaśkowski JMJMW. Mastitis in small ruminants. Elsevier BV 2014;Med. Weter. 2014, 70 (2)(02):67-72.

2. Hawari A, Obeidat M, Awaisheh SS, Al-Daghistani $\mathrm{H}$, Al-Abbadi A, Omar S, et al. Prevalence of mastitis pathogens and their resistance against antimicrobial agents in Awassi sheep in Al-Balqa province of Jordan. Am.J.AnimalVet. Sci. 2014;9(2):116-21.

3. Li SY, Liu SY, Wang HK, Zhang Y, Li ZR, Chen H, et al. The Incidence of Clinical Mastitis and Distribution of Microorganisms in Yangtze Dairy Farm. As. J.Advance Agri.Res. 2018:1-6.

4. Cheng D, Zhu S, Yin Z, Ding W, Mu Z, Su Z, et al. Prevalence of bacterial infection responsible for bovine mastitis. Afr. J. Microbiol. Res.. 2010;4(11):1110-6.

5. Ding Y, Zhao J, He X, Li M, Guan H, Zhang Z, et al. Antimicrobial resistance and virulence-related genes of Streptococcus obtained from dairy cows with mastitis in Inner Mongolia, China. Pharm Biol. 2016;54(1):162-7.

6.Davies JE, editor Origins, acquisition and dissemination of antibiotic resistance determinants. Ciba Found Symp; 1997: Wiley Online Library.

7. Singh K, Chandra M, Kaur G, Narang D, Gupta DK. Prevalence and Antibiotic Resistance Pattern among the Mastitis Causing Microorganisms. Open J Vet Med. 2018 Apr 30;8:54-64.

8. Poisson DM, Evrard ML, Freneaux C, Vivès MI, Mesnard L. Evaluation of CHROMagar ${ }^{\mathrm{TM}}$ StrepB agar, an aerobic chromogenic medium for prepartum vaginal/rectal Group B Streptococcus screening. J Microbiol Methods. 2011 Mar 1;84(3):490-1.

9.Darling CLJJocm. Standardization and evaluation of the CAMP reaction for the prompt, presumptive identification of Streptococcus agalactiae (Lancefield group B) in clinical material. 1975;1(2):171-4.

10.Cockerill FR. Performance standards for antimicrobial susceptibility testing. Approved Standard M100-S20. 2010.

11. Feng J, Wang T, Zhang S, Shi W, Zhang YJPO. An optimized SYBR Green I/PI assay for rapid viability assessment and antibiotic susceptibility testing for Borrelia burgdorferi. J.SpLOS. 2014;9(11):e111809.

12. Albanna A, Sim M, Hoskisson PA, Gillespie C, Rao $\mathrm{CV}$, Aldridge PD. Driving the expression of the Salmonella enterica sv Typhimurium flagellum using flhDC from Escherichia coli results in key regulatory and cellular differences. Sci. rep. 2018 Nov 12;8(1):16705.

13.Tao CW, Hsu BM, Ji WT, Hsu TK, Kao PM, Hsu CP, Shen SM, Shen TY, Wan TJ, Huang YL. Evaluation of five antibiotic resistance genes in wastewater treatment systems of swine farms by real-time PCR. Science of the Total Environment. 2014 Oct 15;496:116-21.

14.Gustafson RH, Bowen RE. Antibiotic use in animal agriculture. J. Appl. Microbiol.. 1997 Nov;83(5):531-41.

15.Barton MD. Antibiotic use in animal feed and its impact on human healt. Nutr. Res. rev. 2000 Dec;13(2):279-99.

16.Kim KS. Efficacy of human immunoglobulin and penicillin $G$ in treatment of experimental group B streptococcal infection. Pediatr Res. 1987 Mar;21(3):289.

17.Ebrahimi A, Lotfalian S, Karimi S. Drug resistance in isolated bacteria from milk of sheep and goats with subclinical mastitis in Shahrekord district. IJVR. 2007 Mar 30;8(1):76-9.

18. Karcic E, Aljicevic M, Bektas S, Karcic BJMs-m. Antimicrobial susceptibility/resistance of Streptococcus pneumoniae. The Academy of Med. Sci. of Bos.\& Her. 2015;27(3):180.

19. Guérin-Faublée V, Tardy F, Bouveron C, Carret G. Antimicrobial susceptibility of Streptococcus species isolated from clinical mastitis in dairy cows. Inter. J. Anti agents. 2002 Mar 1;19(3):219-26.

20. Oliveira L, Ruegg PJJods. Treatments of clinical mastitis occurring in cows on 51 large dairy herds in Wisconsin.J. dairy sci. 2014;97(9):5426-36.

21. Rato MG, Bexiga R, Florindo C, Cavaco LM, Vilela CL, Santos-Sanches I. Antimicrobial resistance and molecular epidemiology of streptococci from bovine mastitis. Vet. Microbiol.. 2013 Jan 25;161(34):286-94. 


\title{
استخدام تقنية RT-PCR للتحري عن الجينات المقاومة لبعض المضادات الحيوية من بكتريا Streptoccous agalactiae
}

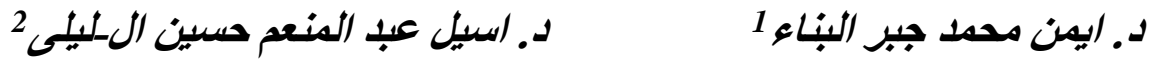

كلية علوم البيئة وتثاناتها, جامعة الموصل , كلئس

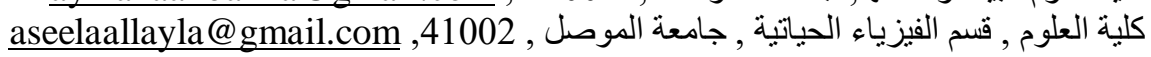

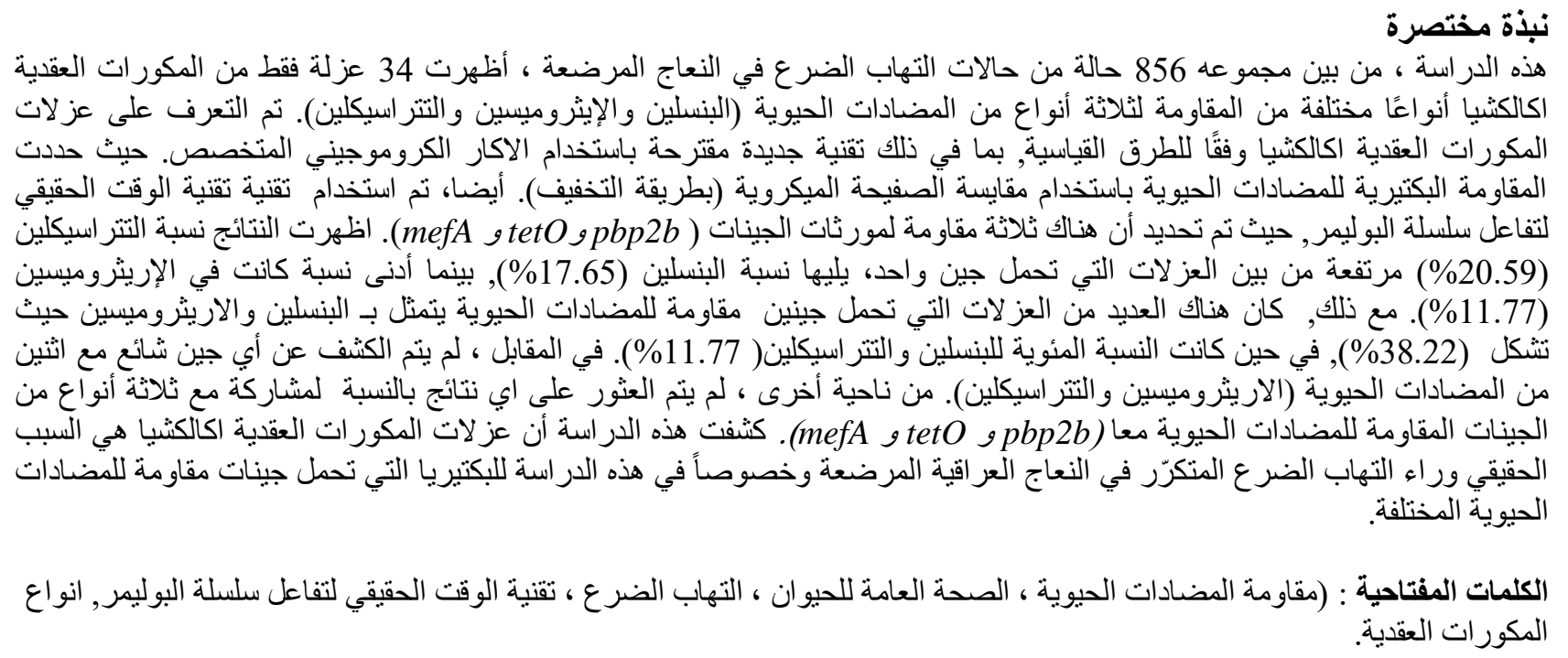

